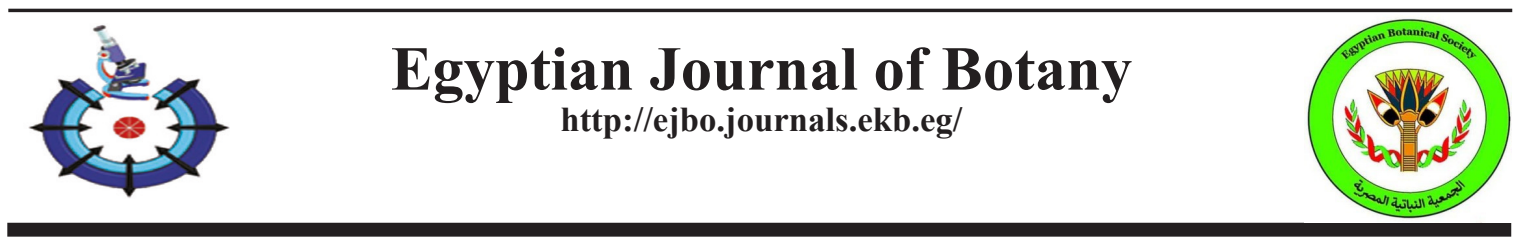

\title{
Anatomical Remarks of Some Species of Silene and Bufonia (Caryophyllaceae), Endemic to Sinai, Egypt
}

\author{
Abbas A. El-Ghamery ${ }^{(1)}$, Ahmed, M. Sadek ${ }^{(1)}$, Ali Gaafar ${ }^{(2) \#}$ \\ (1)Botany and Microbiology Department, Faculty of Science, Al-Azhar University, \\ Egypt; (2)Botany Department, Faculty of Science, New Valley University, El- \\ Kharga,71511- Egypt.
}

\begin{abstract}
A NATOMICAL features of stem and leaf have been studied on four endemic species collected from St. Catherine area, S. Sinai, Egypt. viz. Silene leucophylla Boiss., S. oreosinaica, S. schimperiana and Bufonia multiceps which is provided for the first time. Comparative study was conducted using both light microscope (LM) and scanning electron microscopy (SEM), based on the anatomical structure of the leaf and stem. Druses were found abundantly in both leaf and stem tissue in studied Silene taxa, absent in Bufonia multiceps. Stomata were mostly diacytic or both diacytic and anomocytic were also recorded. Surface view of epidermal cells were straight or undulated. Epicuticular wax platelets have been observed on epidermal and guard cells of S. schimperiana and S. leucophylla. The leaf epidermal and stem anatomical characters were found distinct in each species. Artificial key was provided for the identification of the studied species.
\end{abstract}

Keywords: Anatomy, Bufonia, Caryophyllaceae, Endemic, Flora of Egypt, Leaf, Silene, Stem.

\section{Introduction}

Caryophyllaceae A. Juss. is a large family represented by 81 genera and 2625 cosmopolitan species (Christenhusz \& Byng, 2016). The family is represented in Egypt by 87 species, belonging to 24 genera of these 61 are known from Sinai (El Hadidi \& Hosny, 2000; Boulos, 2009). The family is represented in the present study by 4 species endemics to St. Catherine area viz.: Bufonia multiceps Decne., Silene leucophylla Boiss., $S$. oreosinaica Chowdhuri and S. schimperiana Boiss. The genus Silene comprises approximately 700 to 750 species in 44 sections of which about half occur in the Mediterranean region (Melzheimer 1988, Oxelman et al., 2001, Rautenberg et al., 2012). In Egypt Silene is represented by 29 species, showing great morphological variation of these 11 species known from Sinai (Täckholm, 1974; Hosny et al., 1993; Hosny \& Hadidi, 2000; Boulos, 2009).
Many groups in the genus Silene have high taxonomic complexity especially concerning the macro-morphology (Cood \& Cullen, 1967). The Silene circumscription has been controversial for a long time and several treatments have taxonomically revised the genus (Chowdhuri, 1957a, b; McNeill, 1978; Greuter et al., 1984; Greuter, 1995; Oxelman et al., 2001).

The genus Bufonia includes about 30 annual or perennial herbaceous to small sub shrub by species growing mostly on dry gravely slopes in mountainous regions (Bittrich, 1993; Chrtek \& Kř́sa, 1999; Boulos, 2008) and is distributed in the Mediterranean and Irano-Turnian regions. In Egypt only one species namely Bufona multicepes Decne. was recorded (El Hadidi \& Hosni, 2000; Täckholm, 1974; Boulos, 1999, 2009). A species is restricted to montane wadis with granite rocky ground of mountain areas (Moustafa \& Klopatek, 1995; Abd El-Wahab et al., 2006; Salama et al.,

\#Corresponding author's e-mail: aligaafar2006@gmail.com

Received 24/6/2020; Accepted 11/10/2020

DOI: 10.21608/ejbo.2020.32998.1512

Edited by Prof. Dr. Monier M. Abd El-Ghani, Faculty of Science, Cairo University, Giza 12613, Egypt.

C2021 National Information and Documentation Center (NIDOC) 
2018; Fouad et al., 2019) the species is describing as Critically Endangered (Omar, 2017).

The anatomical characters, for example, trichome types and stomatal kinds of Egyptian endemic taxa of Caryophyllaceae, have not been concentrated previously. In this manner, the objective of the current study is to explore their anatomical attributes utilizing both light (LM) and scanning electron microscopy (SEM) to study the various kinds of tissues, trichomes, and stomata to evaluate the value of these characters for deliberate purposes and to fill the gaps in our insight of Silene and Bufonia in Egypt.
This study aims to provide primary documentation of anatomical characters of stem and leaf of the endemic taxa Silene and Bufonia

\section{Materials and Methods}

Fresh materials were collected from various localities (Musa gorge N: 28.32303 E: 33.960, Wadi Meserdy, Wadi Alarbeen, Wadi Abo Kasaba and Ain Shekia N: 28.55321 E: 33.93482 in Saint Catherine protected area during April and May 2016; the specimens were deposited in the Herbaria of Cairo University (CAI) and AlAzhar University.list of the material studied, with information was shown in Table 1 and Fig. 1.

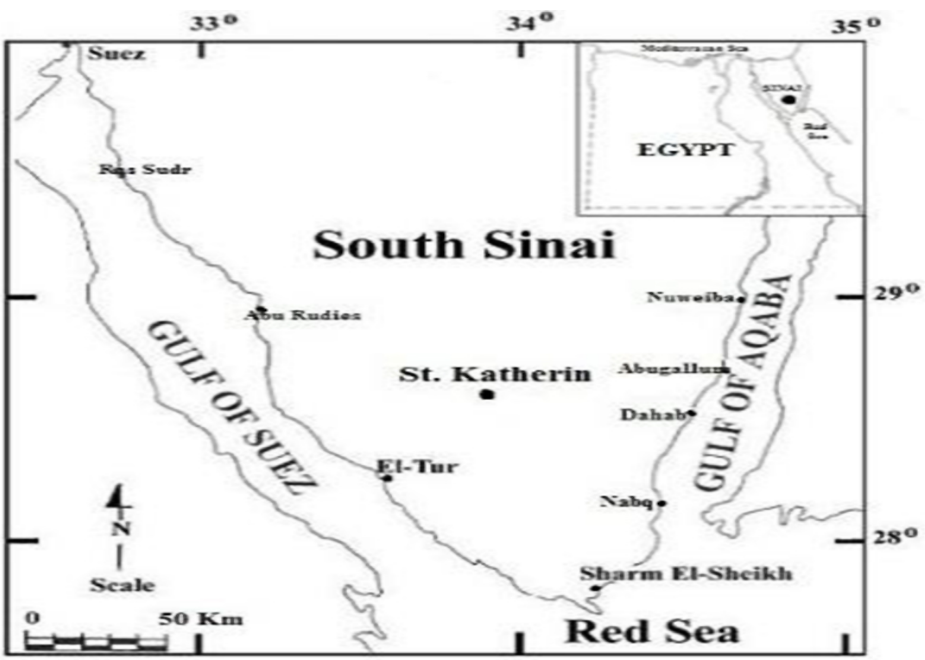

Map of Saint Catherine protected area
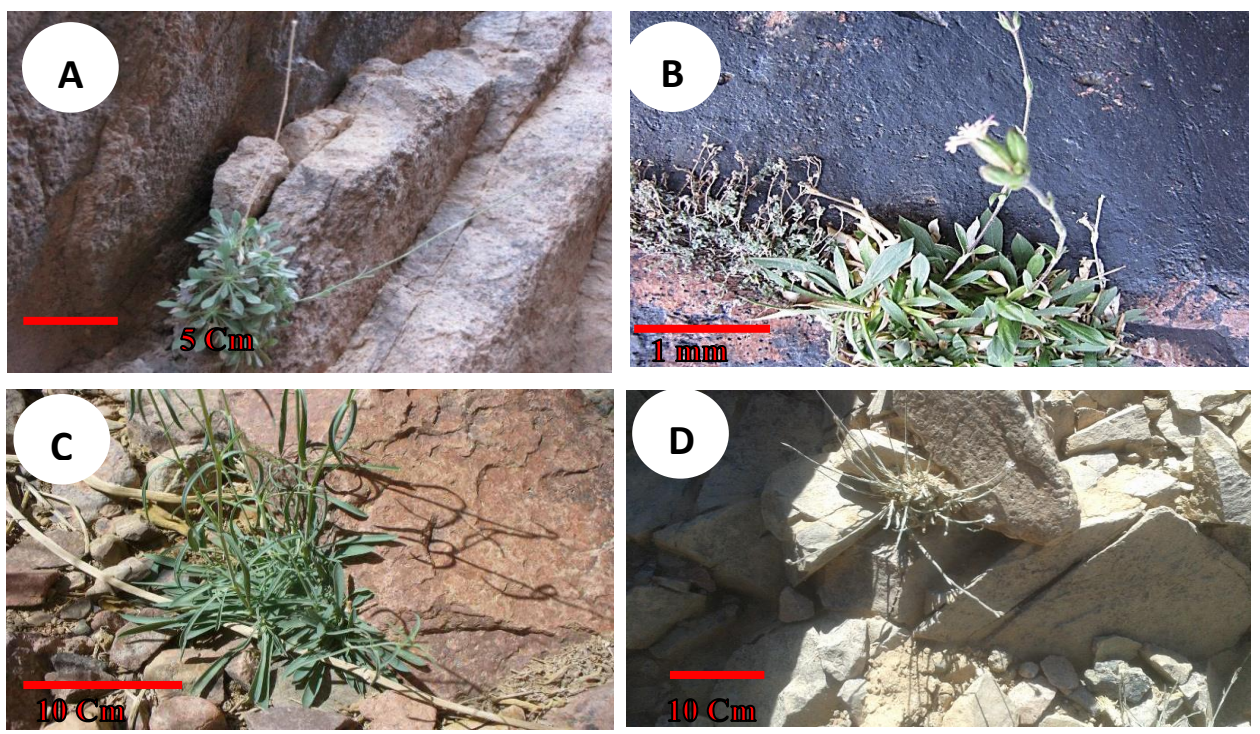

Fig. 1. A: Silene leucophylla, B: Silene oreosinaica, C: Silene schimperiana, D: Bufonia multiceps 
TABLE 1. Species of Silene and Bufonia used in this study and their sectional delimitation, indicate the place and date for each taxon

\begin{tabular}{|c|c|c|c|}
\hline No. & Species & Collection & Habitat \\
\hline $1-$ & Silene leucophylla Boiss. & $\begin{array}{l}\text { - Wadi Meserdy, 4/5/2016, A. M. Sadek; } \\
\text { (Al-Azhar Univ.) } \\
\text {-Ain Shekia, 2/5/2016, A. M. Sadek. (Al } \\
\text { Azhar Univ.) } \\
\text {-Wadi Abo Kasaba 5/5/2016, A. M. Sadek. } \\
\text { (Al-Azhar Univ.) }\end{array}$ & Rocky habitat \\
\hline $2-$ & Silene oreosinaica Chowdhuri. & $\begin{array}{l}\text { - Musa gorges 30/4/2106; A. M. Sadek.(Al- } \\
\text { Azhar Univ.) }\end{array}$ & Rocky-crevicesand slopes \\
\hline $3-$ & Silene schimperiana Boiss. & $\begin{array}{l}\text { - Musa gorges, 30/4/2016; A. M. Sadek. } \\
\text { (Al-Azhar Univ.) } \\
\text {-Wadi Al-Arbiaen 30/4/2016, A. M. Sadek. } \\
\text { (CAI, Al Azhar Univ.) }\end{array}$ & Rocky slopes and crevices \\
\hline $4-$ & Bufonia multiceps Decne. & $\begin{array}{l}\text { Wadi Al Ferah 30/4/2016; A. M. Sadek. } \\
\text { (Al-Azhar Univ.) } \\
\text { Wadi Al-Arbiaen 30/4/2016, A. M. Sadek. } \\
\text { (Al-Azhar Univ.) } \\
\text { Ain Shekia 2/5/2016; A. M. Sadek. (CAI, } \\
\text { Al-Azhar Univ.) }\end{array}$ & Rocky slopes. \\
\hline
\end{tabular}

For light microscopic study (LM), 3-5 specimens of internode and mature blade were taken from basal leaflets. The specimens processed according to paraffin wax method of Johansen (1944) to prepare samples for microtome sectioning at $10-15 \mu \mathrm{m}$ thickness. Sections were fixed on glass slides by means of Haupt's adhesive (1gm gelatin dissolved in $50 \mathrm{~mL}$ warm distilled water then $7.5 \mathrm{~mL}$ glycerol added + small phenol crystal then kept in refrigerator for $24 \mathrm{hrs}$. till solidification) and left to dry for $24 \mathrm{hrs}$. Then sections were stained with Safranin-Fast green standard double stain and mounted in Canada balsam (Sass, 1961).

For epidermal examination, three pieces of lamina were embedded in $\mathrm{KOH} \mathrm{5 \%}$ for 24-48 hrs.; stomata and trichomes of upper and lower epidermis were examined. Terminology followed Barthlott (1981, 1990), Barthlott et al. (1998), and Stearn (1996).

For scanning electron microscopy (SEM), leaves were mounted on stubs using doublesided adhesive tape, then coated with Nano gold then examined and photographed with JIOL JSM SEM at the Electron Microscope unit at The Regional Center for Mycology and Biotechnology, Al-Azhar University, Cairo, Egypt. For measurements and calibration stage micrometer was used as well as image $\mathrm{J}$ software and photographed by using stereomicroscope equipped with Premiere (MA88-900) digital camera.

\section{Results}

Silene leucophylla Boiss

Stem circular in cross section, epidermis uniseriate with oblong cells. Cortex with 3-4 layers of chlorenchyma tissue followed by 6 layers of pericyclic fibers. Vascular cylinder consists of many collateral vascular bundles arranged in a cycle. Each bundle contains few phloem and xylem elements. Large pith of thin parenchyma present. (Plate 1, Figs. 1-2). Leaf transection revealed wavy epidermis, uniseriate with cubic cells. Midrib arc shaped, penetrated with small collateral vascular bundle with arc shape. The bundle consists of few phloem elements, many xylem elements. Mesophyll dorsiventral, with two continuous palisade layers followed by 4-5 layers of spongy tissue. Druses present in leaf and stem. (Plate 1, Figs. $3 \& 4$ ). Stomata anomocytic, diacytic (Plate 1, Fig. 5). Trichomes unicellular, un-branched and nonglandular (Plate 1, Fig. 6). In SEM, epidermal cells with undulated cell wall; stomata are semidepressed and cuticle ultrastructure with highly dense epicuticular wax platelets on epidermal and guard cells (Plate 1, Figs. $7 \&$ 8), (Table 2). 


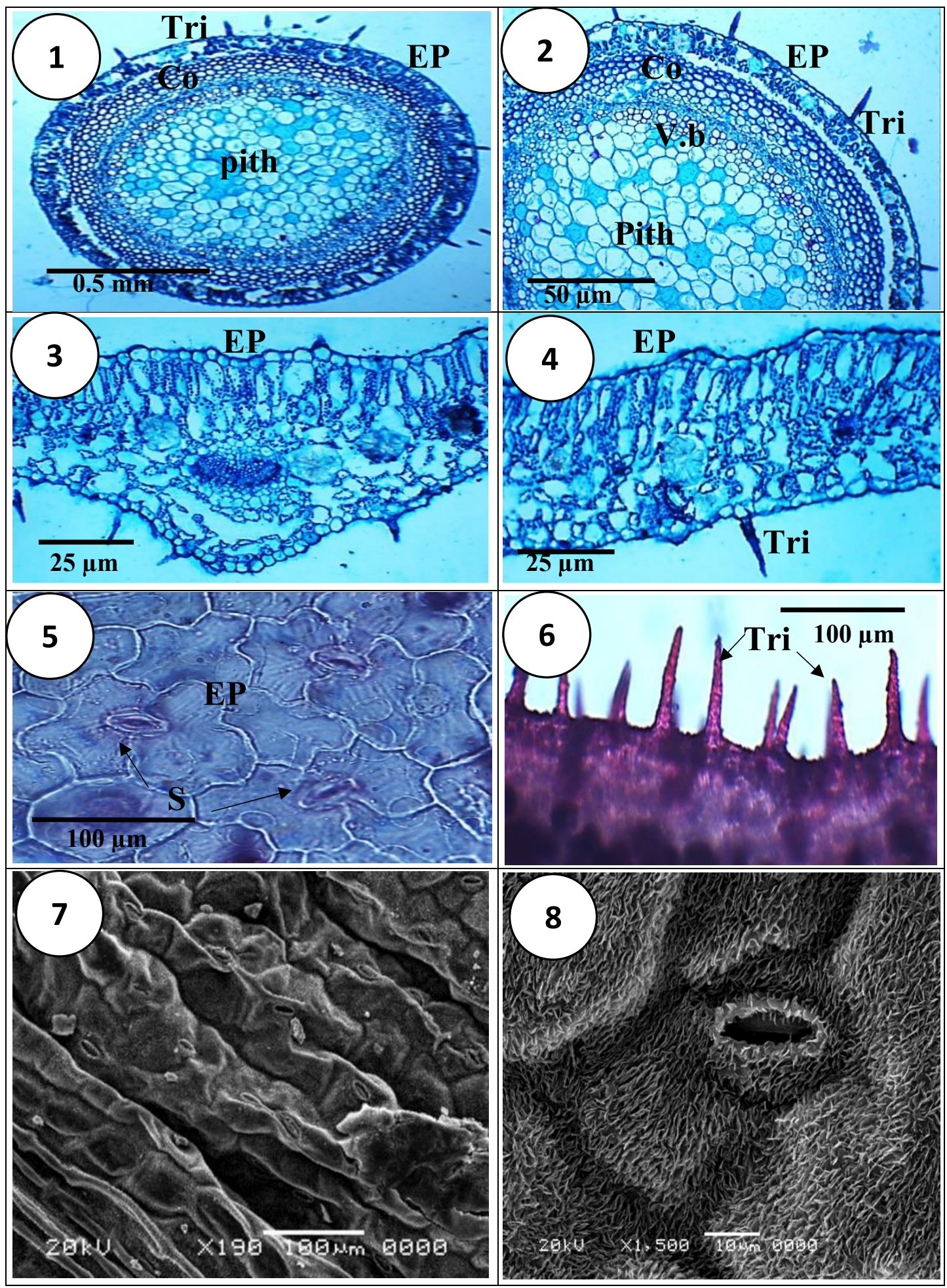

Plate 1. (Figs. 1-8). Silene leucophylla: Micrograph stem and leaf anatomy, 1-2: Stem TS; 3 - 4: Leaf TS; 5, 7, 8: Stomata; 6: Trichome on L.M and SEM [Tri= Trichome, EP $=$ Epidermis, $\mathrm{Co}=\mathrm{Cortex}, \mathrm{V} . \mathrm{b}=$ Vascular bundles, $\mathrm{S}=$ Stomata] 
TABLE 2. Anatomical characters of the stem and leaf of the studied taxa.

\begin{tabular}{|c|c|c|c|c|}
\hline $\mathrm{C}_{\text {Characters }}^{\text {Studied tax }}$ & S. leucophylla & S. oreosinaica & S.schimperiana & B. multiceps \\
\hline \multicolumn{5}{|l|}{ Stem } \\
\hline Cross section & Circular & Fusiform & Circular & Rounded \\
\hline Epidermal cell shape & Uniserate- oblong & Uniserate- oblong & Uniserate- oblong & Uniseriate- oblong \\
\hline Cortex layers & $3-4$ & $5-7$ & $3-4$ & $5-7$ \\
\hline Parynchyma layers & 6 & $7-8$ & $8-11$ & $1-2$ \\
\hline Vascular bundle No. & Many & 6 & 7 & 10 \\
\hline Pith & Large & Large & Medium & Medium \\
\hline Calcium oxalate & Druses & Druses & Druses & Absent \\
\hline \multicolumn{5}{|l|}{ Leaf } \\
\hline Epidermal cell shape & Uniseriate- cubic & Uniseriate- oblong & Uniseriate- cubic & Uniseriate- oblong \\
\hline Midrib vascular bundle & Arc- shaped & Ovate & Ovate & Ovate \\
\hline Calcium oxalate & Druses & Druses & Druses & Druses \\
\hline Spongy palsied tissue & $4-5$ & $4-5$ & $4-5$ & $4-6$ \\
\hline Stomata type & $\begin{array}{l}\text { Diacytic and } \\
\text { anomocytic }\end{array}$ & Diacytic & Diacytic & Diacytic and anomocytic \\
\hline Trichomes type & $\begin{array}{l}\text {-Unicellular } \\
\text {-Unbranched } \\
\text {-Non glandular }\end{array}$ & $\begin{array}{l}\text {-Multicellular } \\
\text {-Unbranched } \\
\text {-Non glandular }\end{array}$ & $\begin{array}{c}\text {-Tiny } \\
\text {-Unicellular } \\
\text {-Unbranched } \\
\text {-Non glandular }\end{array}$ & $\begin{array}{l}\text {-Multicellular } \\
\text {-Unicellular } \\
\text {-Unbranched } \\
\text {-Non glandular }\end{array}$ \\
\hline
\end{tabular}

Silene oreosinaica Chowdhuri

Stem fusiform in cross section, epidermis uniseriate with oblong cells, Cortex 5-7 layers of thin parenchyma followed by 7-8 layers of pericyclic sclerenchyma tissue. Vascular cylinder consists of 6 collateral vascular bundles, with elliptic shape; each consists of many xylem, phloem elements. Pith contains large thin parenchyma cells. (Plate 2; Figs. 1 \& 2). Leaf transection revealed that epidermis uniseriate with oblong cells. Midrib penetrated with small collateral vascular bundle with ovate shape. The bundle consists of few phloem elements, many xylem elements. Midrib ground tissue palisade, thin parenchyma and angular collenchyma. Mesophyll dorsiventral, two continuous palisade layers followed by 4-5 layers of spongy tissue (Plate 2; Figs. 3 \& 4). Druses present in leaf and stem (Plate 2; Figs. 2, 3 \& 5); epidermal cells with straight walls; stomata diacytic only
(Plate 3; Fig. 1). In SEM stomata semi-depressed and cuticle ultrastructure without epicuticular wax platelets (Plate 3; Figs. 3 \& 4). Trichomes multicellular, unbranched, non-glandular (Plate 3; Fig. 2), (Table 2).

\section{Silene schimperiana Boiss}

Stem outline circular, epidermis uniseriate with oblong cells. Cortex with 3-4 layers of chlorenchyma tissue followed by 8-11 layers of pericyclic fibers. Vascular cylinder consists of 7 collateral vascular bundles arranged in a cycle. Each bundle contains few phloem elements, many xylem elements. pith with thin parenchyma cells (Plate 4; Figs. 1 \& 2). Leaf Transection revealed that epidermis uniseriate with cubic, elongated cells. Midrib rounded, penetrated with small collateral vascular bundle with ovate shape. The bundle, consists of few phloem elements, many xylem 
elements. Mesophyll dorsiventral, two continuous palisade layers followed by 4-5 layers of spongy tissue. (Plate 4; Figs. 3, 4, 5 \& 6). Druses present in leaf and stem. Epidermal cells straight wall; stomata diacytic only (Plate 4; Fig. 7), Trichomes tiny unicellular, unbranched, non-glandular. (Plate 4; Fig. 8) on SEM stomata semi-depressed with slightly dense epicuticular wax platelets on both epidermal cells and guard cells. Epidermis papillate (Plate 4; Figs. 9 \&10), (Table 2).

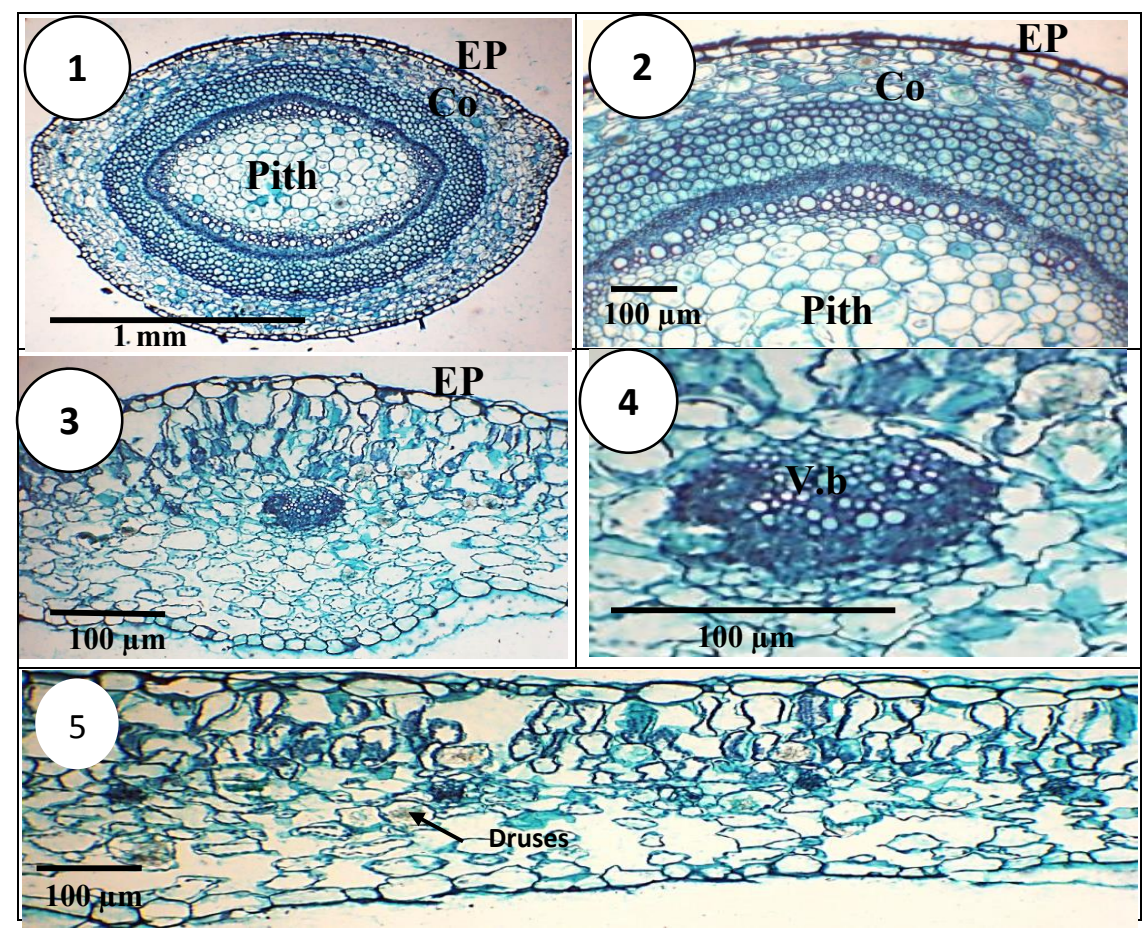

Plate 2. (Figs. 1-5). Silene oreosinaica: Micrograph stem and leaf anatomy, 1-2: Stem TS; 3-5: Leaf [EP= Epidermis, $\mathrm{Co}_{\mathbf{0}}=$ Cortex, $\mathrm{V} . \mathrm{b}=$ Vascular bundles)
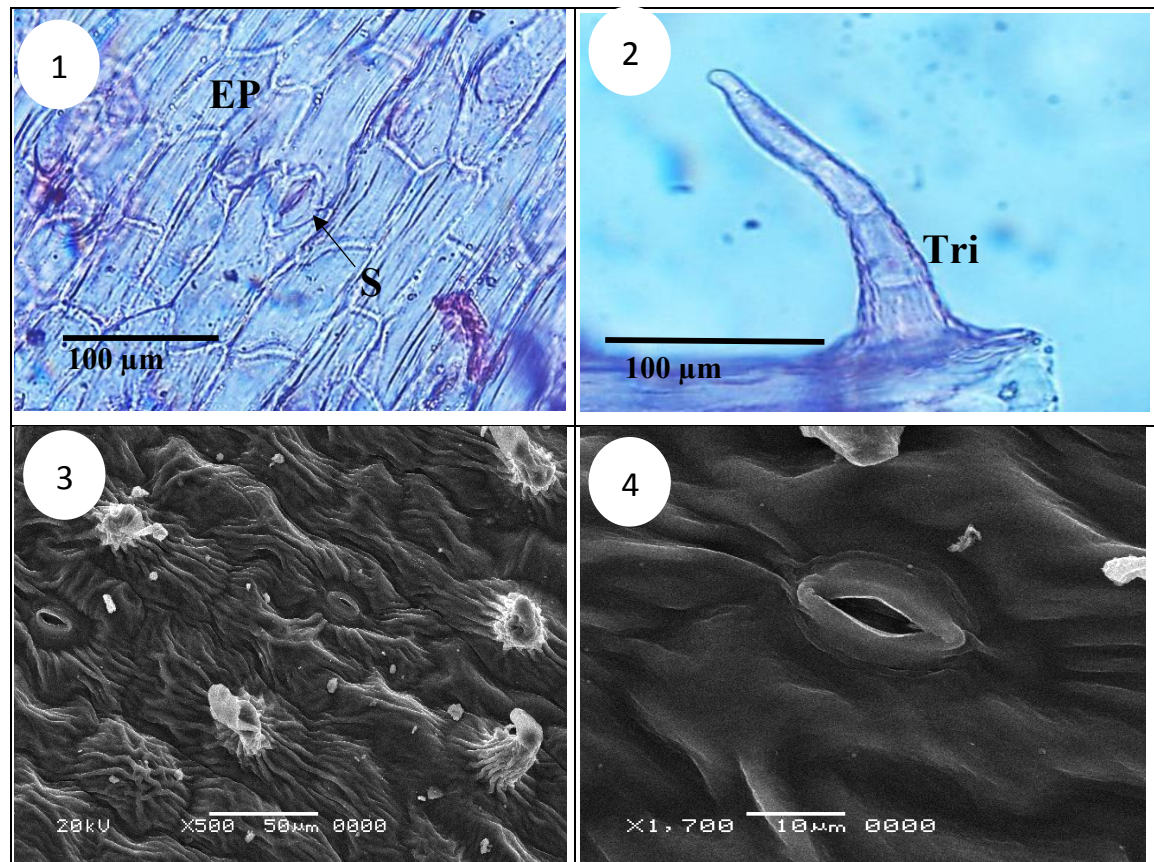

Plate 3. Figs. 1-4. Silene oréosinaica, 1: Stomata; 2: Trichome oñ L.M and 3,4: SEM (Doŕsäl víew of stomata and trichomes) $[$ Tri= Trichome, $\mathbf{E P}=$ Epidermis, $\mathrm{S}=$ Stomata $]$

Egypt. J. Bot. 61, No.1 (2021) 


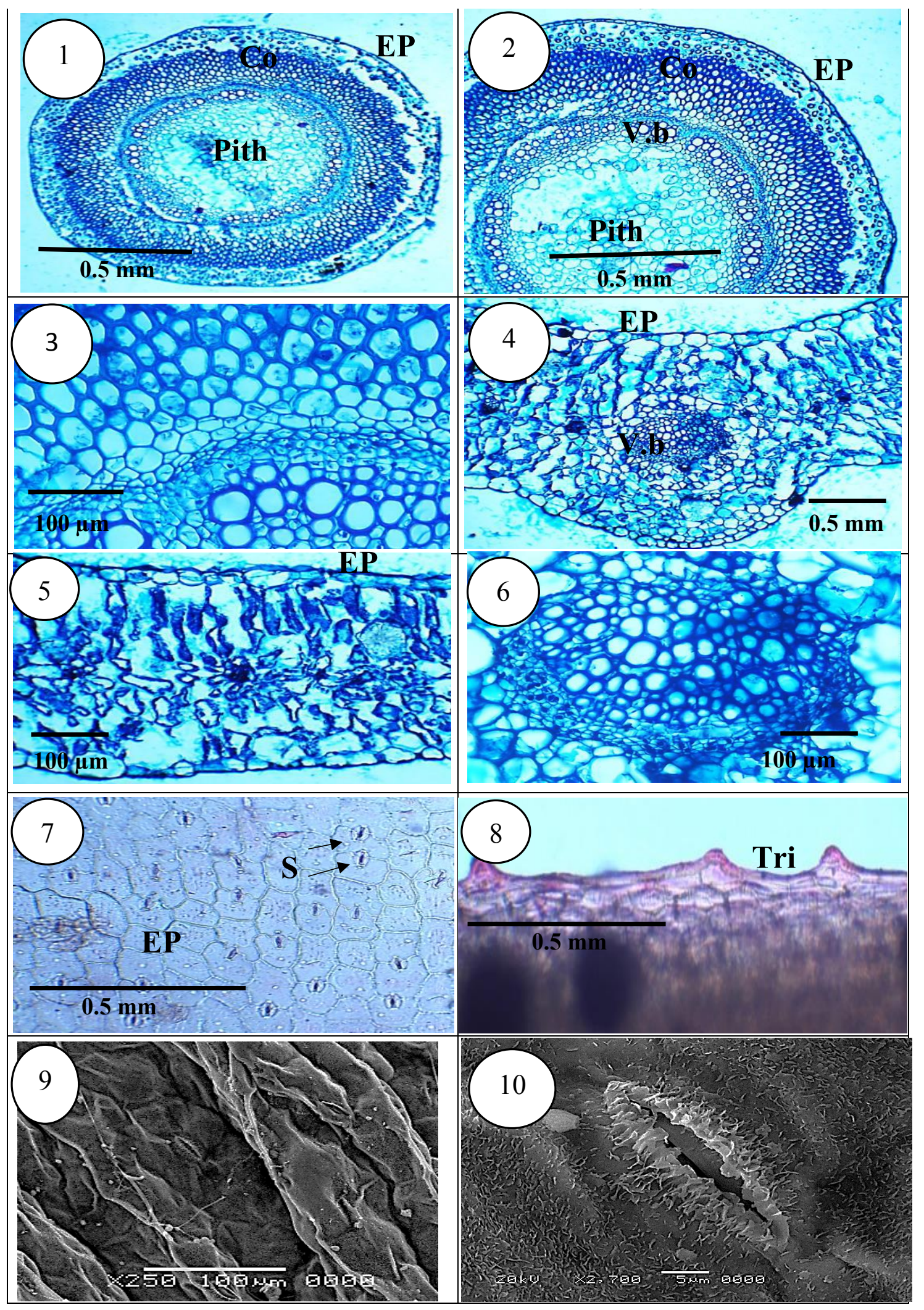

Plate 4. Figs. 1-10. Silene schimperiana Micrograph stem and leaf anatomy, 1-2: Stem TS.; 3-6: Leaf TS.; 7: Stomata; 8: Trichome (unicellular) on L.M.; 9-10: SEM. Dorsal view of stomata and trichrome $[$ Tri $=$ Trichome, $\mathbf{E P}=$ Epidermis, $\mathbf{C o}=$ Cortex, $\mathbf{V} . \mathbf{b}=$ Vascular bundles, $\mathrm{S}=$ Stomata] 


\section{Bufonia multiceps Decne}

Stem circular in cross section. Epidermis uniseriate with oblong cells. Cortex consists of 5-7 layers of chlorenchyma. Pericycle of 1-2 discontinuous layers of fibers. Vascular cylinder consists of 10 collateral vascular bundles arranged in a ring. Pith with thin parenchyma cells. Epidermis of leaves uniseriate with oblong, cubic cells in transection. Midrib arc shaped with one large, ovate, collateral vascular bundle with 4 layers of angular collenchyma above and 6 layers below. The vascular bundle consists of few phloem elements and many xylem elements. Mesophyll isobilateral consists of $4-6$ layers of palisade tissue. (Plate 5; Figs. 1-6). Epidermal cells with undulated wall,Stomata diacytic and anomocytic (Plate 6, Figs. 1 \& 3). In SEM stomata semi-depressed and cuticle ultrastructure without epicuticular wax platelets (Plate 6; Figs. 5 \& 6). Trichomes unicellular and multicellular, unbranched, glandular and non-glandular. (Plate 6, Figs., 2 \& 4) (Table 2).

\section{Discussion}

The present study aims to investigate anatomical features of 4 taxa belonging to Caryophyllaceae endemic to St. Catherine, S Sinai, to determine the various types of tissues, trichomes, stomata and epidermal features to evaluate the usefulness of these characters for systematic purposes. The anatomical characteristics in this work give the first detailed description of 3 Silene species and Bufonia multiceps.

The anatomical structure of the leaves of some Silene species showed a significant variation in anatomical structure and the importance of the shape and size of the epidermal cells, hairs and crystals in the separation of species (Keshavarzi et al., 2014). In the studied taxa, stem cross section was mostly circular or fusi form in $S$. oreosinaica with multi-layered parenchymatous cortex, presence of an outer sclerenchyma tissue and an inner pericyclic ring each consisting of at least of two rows of fibers, a large central pith and continuous xylem vessels with variable thickness surrounding the central pith. Stomata were mostly diacytic, although anomocytic stomata were also recorded in Silene leucophylla and Bufonia multiceps.

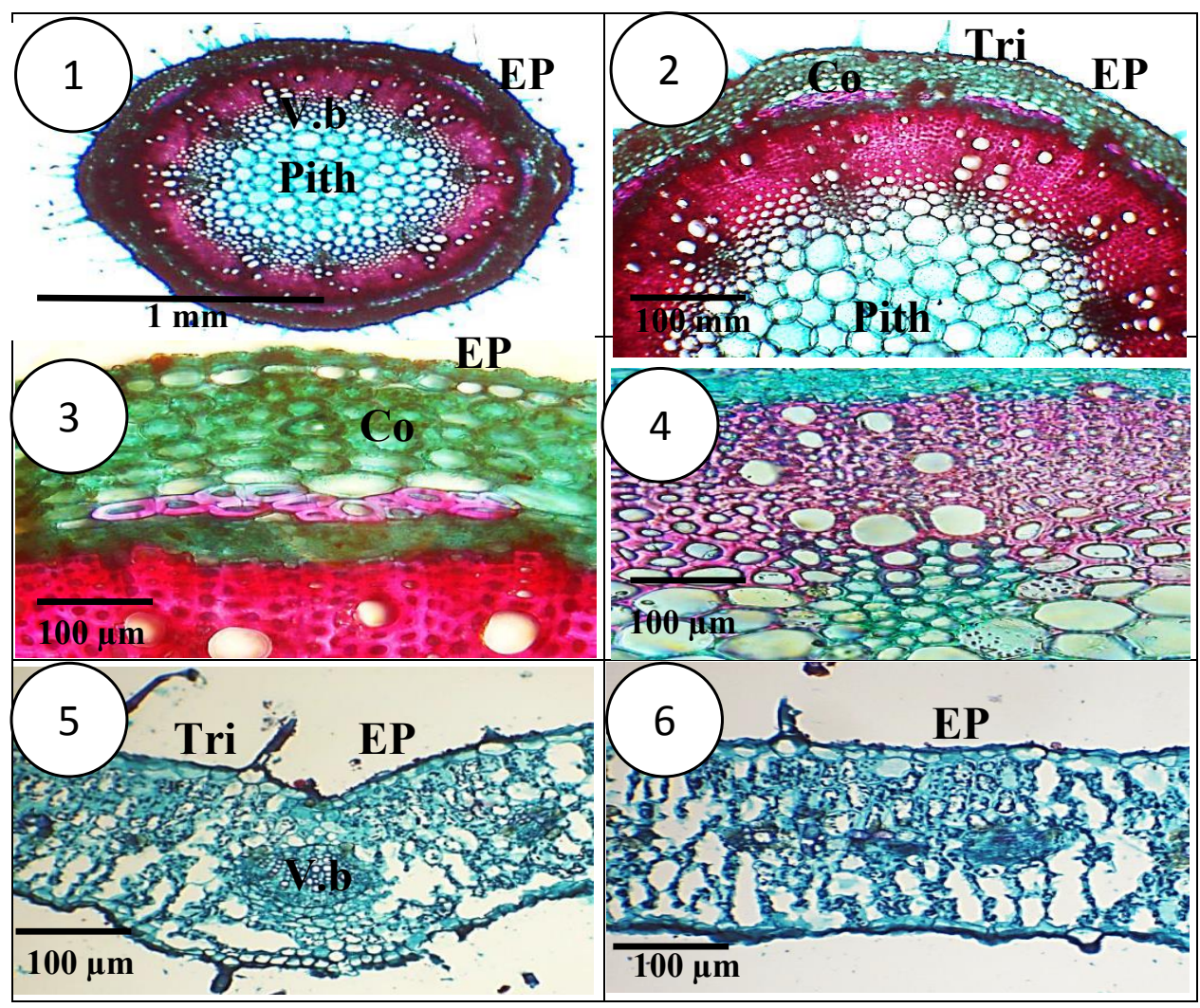

Plate 5. (Figs. 1-6). Buofonia multiceps Micrographs of stem and leaf anatomy, 1-2: Stem TS.; 3-4: Cortex and vascular bundles; 5: Lower leaf midrib TS; 6: Mesophyll [Tri= Trichome, EP= Epidermis, $\mathrm{Co}=$ Cortex, V.b= Vascular bundles]

Egypt. J. Bot. 61, No.1 (2021) 


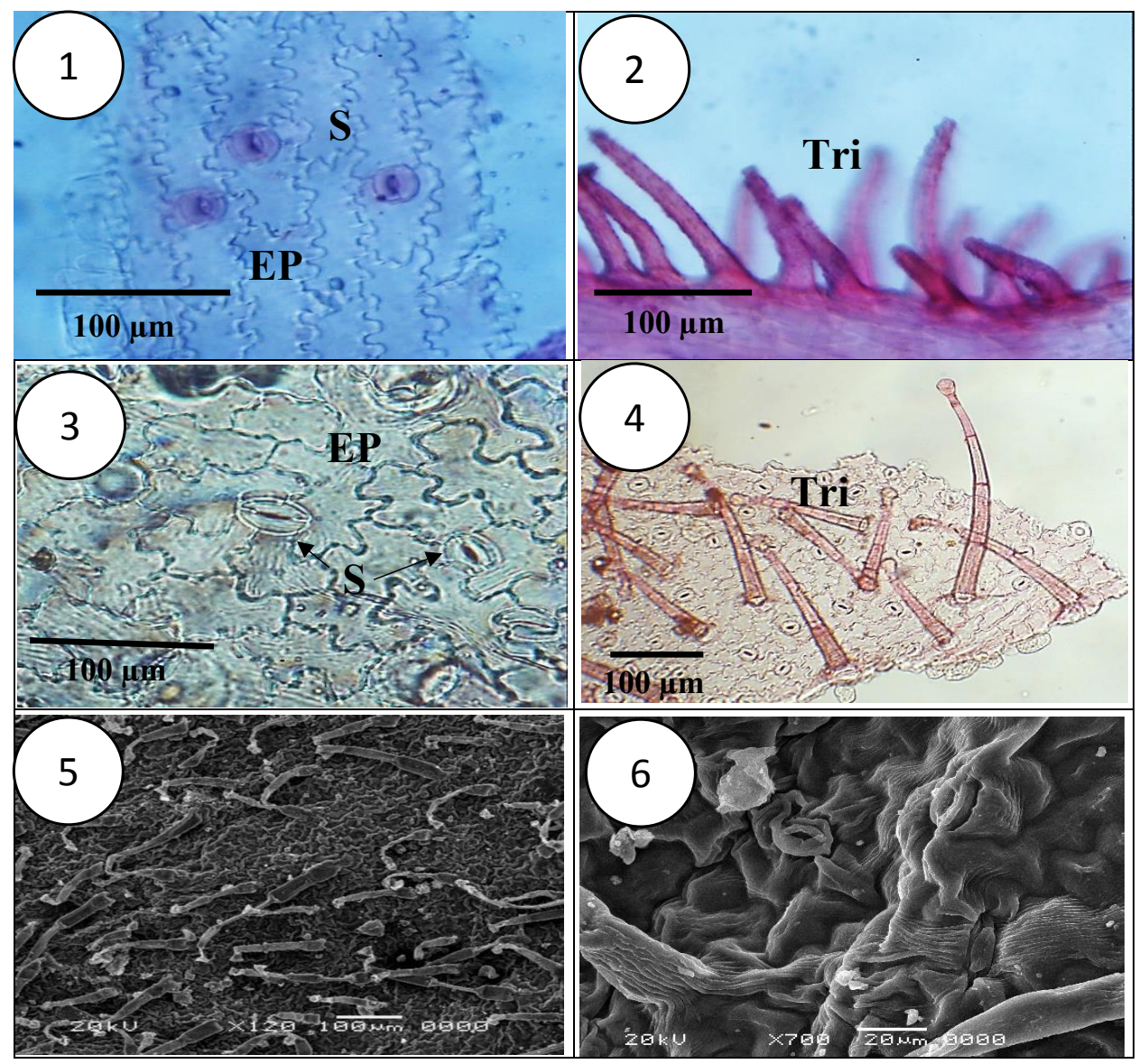

Plate 6. (Figs. 1-6). Buofonia multiceps Surface view of upper and lower leaves, 1-2: LM of stomata and trichomes of the upper leaves; 3-4: Stomata and trichomes of the lower leaves; 5- 6: SEM of stomata and trichomes of the lower leaves [Tri= Trichome, $\mathbf{E P}=$ Epidermis, $\mathrm{S}=$ Stomata]

Metcalfe \& Chalk (1950) described several types of trichomes unicellular simple, long or short uniseriate, uniseriate with glandular cell at the apex, and branched in different genera of Caryophyllaceae. In the present study, unicellular and multicellular, unbranched, non-glandular or glandular hairs were recorded in addition to papillae in Silene schimperiana. Druses crystals were observed in stem and leaves of studied taxa of Silene; while in Bufonia multiceps no druses were recorded although Mousavi et al. (2019) recorded the presence of druses in all studied taxa of Bufonia from Iran. Dense epicuticular wax was observed on epidermal and guard cells of $S$. leucophylla whereas the wax was moderate in $S$. schimperiana and absent in the rest of the studied taxa.

An artificial key is prepared based on anatomical characters for identification purposes as follows:
1. a. Stem circular, epidermis uniseriate with oblong cells; cortex with 3-4 layers of chlorenchyma tissue followed by 6 layers of pericyclic fibers. S. leucophylla

1.b. Stem fusiform, epidermis uniseriate with oblong cells; cortex with 5-7 layers of thin parenchyma tissue followed by 7-8 layers of pericyclic sclerenchyma tissue 2

2.a. Vascular cylinder consists of 6 collateral vascular bundles, with elliptic shape, each consists of many xylem, phloem elements...

..S. oreosinaica

2.b. Vascular cylinder consists of 7 collateral vascular bundles, each consists of many xylem elements, few phloem elements.

3

3. a. Stomata diacytic only, semi-depressed with slightly dense epicuticular wax platelets, 
epidermal cell straight wall S. schimpeiana

3.b. Stomata diacytic and anomocytic, semidepressed without epicuticular wax platelets, epidermal cells with undulated wall....B. multiceps

\section{Conclusion}

The anatomical characteristics of stem and leaf, including epidermal cells, and stomata type were important for the identification and taxonomy of the four endemic species collected from the area of St. Catherine, S Sinai, Egypt. In this analysis, 3 species of Silene and one species of Bufonia multiceps were assessed. To build a dichotomous key for easy identification of each of the studied taxa, the most accurate stem and leaf anatomical attributes have been used.

Acknowledgement: We would like to express our gratitude to Prof. Dr. Hasnaa A. Hosni, The Herbarium, Faculty of Science, Cairo University for revision and valuable discussions in this manuscript.

Conflict of interest: The authors reported no potential conflict of interest.

Authors contribution: This work was carried out in collaboration between all authors. Abbas A. ElGhamery and Ahmed, M. Sadek conceived of the presented idea. Ahmed, M. Sadek and Ali Gaafar performed the measurements and processed the experimental data. Abbas A. El-Ghamery and Ali Gaafar discussed the results and contributed to the final manuscript.

\section{Ethical approval: Not applicable.}

\section{References}

Abd El-Wahab, R.H., Zaghloul, M.S., Moustafa, A.A. (2006) Vegetation and Environment of Gebel Serbal, South Sinai, Egypt. Catrina Journal, 1(2), 9-20.

Barthlott, W.(1981) Epidermal and seed surface characters of plants: Systematic applicability and some evolutionary aspects. Nordic Journal of Botany, 1, 345-355.

Barthlott, W. (1990) Scanning electron microscope of the epidermal surface in plants. In: "Scanning
Electron Microscopy in Taxonomy of Functional Morphology", Claugher, D. (Ed.), pp. 69-83. Clarendon, Oxford.

Barthlott, W., Neinhuis, C., Cutler, D., Ditsch, F., Meusel, I., Theisen, I., Wilheimi, H. (1998) Classification and terminology of plant epicuticular waxes. Botanical Journal of Linnaean Society, 126, 237-260.

Bittrich, V. (1993) Caryophyllaceae. In: "Families and Genera of Vascular Plants", Kubitzki, K. (Ed.), pp. 206-236. Springer Verlag, Berlin.

Boulos, L. (1999) "Flora of Egypt". Vol. 1. Al Hadara Publishing, Cairo, Egypt, 419p.

Boulos, L. (2008) Flora and vegetation of the Deserts of Egypt. Flora Mediterranea, 18, 341- 359.

Boulos, L. (2009) "Flora of Egypt Checklist". Revised annotated edition, Al Hadara Publishing, Cairo, Egypt.

Chowdhuri, P.K. (1957a) Silene sect. Tunicoideae (Boiss.) Chowdhuri Notes from the Royal Botanic Garden, Edinburgh, 22, 263-281.

Chowdhuri, P.K. (1957b) Studies in the genus Silene. Notes from the Royal Botanic Garden Edinburgh, 22, 221-278.

Christenhusz, M.J.M., Byng, J.W. (2016) The number of known plants species in the world and its annual increase. Phytotaxa, 261(3), 201-217.

Chrtek, J., Křísa, B. (1999) A revision of Asian species of the genus Bufonia L. Acta Universitatis Carolinae Biologica, 43, 77-118.

Cood, M.J.E., Cullen, J. (1967) Silene L. In: "Flora of Turkey and the East Aegean Islands", Davis, P.H. (Ed.), Vol. 2. $1^{\text {st }}$ ed. pp. 179-222, Edinburgh University Press, Edinburgh, UK.

El Hadidi, M.N., Hosni, H. (2000) Conservation and threats. In: "Flora Aegyptiaca", M.N. El Hadidi (Ed.). Vol. 1(1), pp. 105-151. The Palm Press \& Cairo University Herbarium, Cairo.

Fouad, A.S., Hafez, R.M., Hosni, H.A. (2019) Authentication of three endemic species of the Caryophyllaceae from Sinai Peninsula Using DNA barcoding. Egyptian Journal of Botany, 
59(2), $483-491$.

Greuter, W.(1995) Silene (Caryophyllaceae) in Greece: A subgeneric and sectional classification. Taxon, 44, 543-581.

Greuter, W., Burdet, H.M., Long, G. (1984) "MedChecklist", 1. Geneve \& Berlin.

Hosny, A.I., El Hadidi, M.N., Shamso, E. (1993) Taxonomic study of Silnoideae (Caryophyllaceae) in Egypt. 1 systematic revision of the genus Silene L. Taeckholmia, 14, 1-36.

Hosny, A.I., El Hadidi, M.N. (2000) Caryophyllaceae. In: "Flora Aegyptiaca", M.N. El Hadidi (Ed.), Vol.1 (2), pp. 103- 160. The Palm Press \& Cairo University Herbarium.

Johansen, D.A. (1944) "Plant Microtechnique". McGraw-Hill, New-York, 523p.

Keshavarzi, M., Mahdavinejad, M., Sheidai, M., Gholipour, A. (2014) Anatomical study of some Silene L. species of Lasiostemones Boiss. section in Iran. Acta Biologica Szegediensis, 58, 15-19.

McNeill, J. (1978) Silene alba and S. dioica in North America and in the generic delimitation of Lychnis, Melandrium and Silene (Caryophyllaceae). Canadian Journal of Botany, 56, 297-308.

Melzheimer, V. (1988) Caryophyllaceae: Silene L. In: "Flora Iranica", Rechinger, K.H. (Ed.), Vol. 163, pp. 341-508. Graz, Austria.

Metcalfe, C.R., Chalk, L. (1950) "Anatomy of the Dicotyledons". Oxford, Clarendon Press, UK, 330p.

Mousavi1, S., Pirani, A., Zarre, S. (2019) Stem anatomy and its systematic implication in Bufonia
(Caryophyllaceae, Sagineae) and related genera. Phytotaxa, 394(2), 148-160.

Moustafa, A.A., Klopatek, J.M. (1995) Vegetation and landforms of the Saint Catherine area, southern Sinai, Egypt. Journal of Arid Environments, 30, 385-395.

Omar,K.(2017)Bufoniamulticeps. The IUCNRedListof Threatened Species 2017: e.T84119945A84119949. https://dx.doi.org/10.2305/IUCN.UK.2017-3. RLTS.T84119945A84119949.en.

Oxelman, B., Liden, M., Rabeler, R.K., Popp, M. (2001) A revised generic classification of the tribe Sileneae (Caryophyllaceae). Nordic Journal of Botany, 20, 743-748.

Rautenberg, A., Sloan, D.B., Alden, V., Oxelman, B. (2012) Phylogenetic relationships of Silene multinervia and Silene Section Conoimorpha (Caryophyllaceae). Systematic Botany, 37(1), 226237.

Salama, F., Abd El-Ghani. M.M., Gadalla, M., Ramadan, T., Galal, H., Gaafar, A. (2018) Vegetation patterns and floristic composition along elevation gradient on Jabal Musa, South Sinai, Egypt. Catrina Journal, 17(1), 41-57.

Sass, J.E. (1961) "Botanical Microtechnique", $3^{\text {rd }}$ ed. Iowa State University Press, Ames, Iowa, USA. $228 \mathrm{p}$.

Stearn, W.T. (1996) "Botanical Latin". David \& Charles (Eds.), $4^{\text {th }}$ ed. London, 546p.

Täckholm, V. (1974) "Students' Flora of Egypt". $2^{\text {nd }}$ ed. Cairo University, 888p. 


\section{ملاحظات تشريحية لبعض أنواع السيلين والعَدمَة الفصيلة القرنفلية ، المتوطنة في سيناء ، مصر تصريح \\ عباس أحمد الغمري(1)، أحمد محمد صادق(1)، علي جعفر (2)

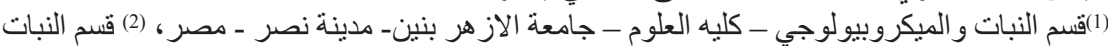 و الميكروبيولوجي - كليه العلوم - جامعة الو ادي الجديد ـ مدينة الخارجة 11517 115ــ مصر.}

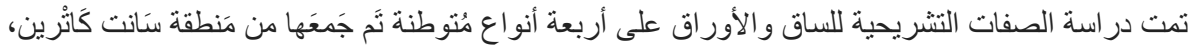

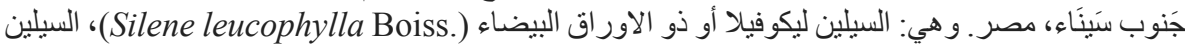

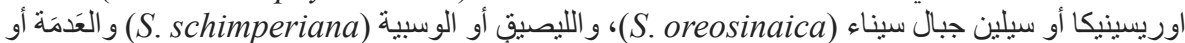

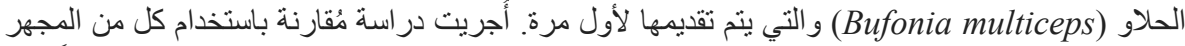

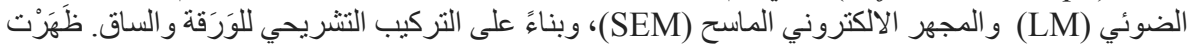

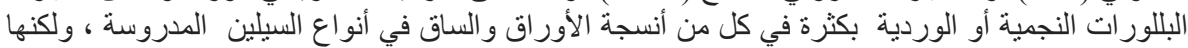

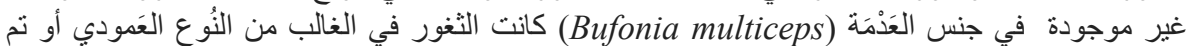

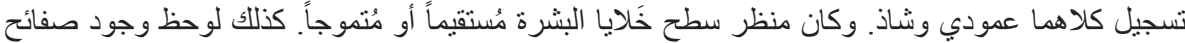

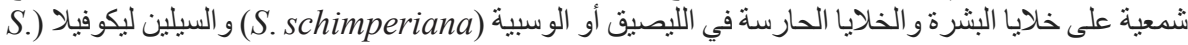
(leucophylla مفتاح اصطناعي لتحديد الأنو اع المدروسة. 